\title{
EDITORIAL: GOVERNANCE AFTER LISBON
}

If the European Union (EU) has a particular skill, it is launching new initiatives. If it has a particular weakness, it is a tendency to have too many initiatives to which to devote its resources.

Spring 2000 saw the launch of the Lisbon Strategy of economic and social reform. December 2000 witnessed the proclamation of a Charter of Fundamental Rights and agreement on further revisions to the founding treaties. A year later, the European Council in Laeken launched the process to create a Convention to form the basis for further revisions to the Treaties. Meanwhile the accession process continued with ten new Member States joining the Union in May 2004. Some months later, the Heads of Government and State put their signatures to a Treaty establishing a Constitution for Europe based on the draft Treaty adopted by the Convention presided over by Valéry Giscard d'Estaing.

Perhaps understandably, the 'big' agendas of enlargement and constitutional reform have dominated analysis of the EU both in terms of its processes of decision-making and also as regards its identity and future. Nonetheless, as the rejection of the Constitutional Treaty in the referendums in the Netherlands and France demonstrated, citizens are not unconcerned by what sort of Europe - in substantive economic and social terms - is being created and which might be institutionalised in the text of the Constitution. To that extent, the referendum on the Constitution was also a referendum on the sorts of economic and social reforms that the Lisbon Strategy was intended to stimulate. But what has Lisbon actually changed?

With this context in mind, and funded by the UK Economic and Social Research Council, a series of research seminars were held to consider the Lisbon Strategy and the governance architecture that is being developed to implement the Strategy. The papers presented here were initially presented at a workshop held at the Europa Institute, University of Edinburgh in April 2006, which brought together a group of graduate students researching different policy domains and issues pertaining to the Lisbon Strategy. The Journal of Contemporary European Research is delighted to publish the final papers from the workshop in this special issue.

Of some importance to the general view that the Lisbon Strategy has resulted in poor 'implementation' has been the contested evaluations of the Lisbon governance architecture, and in particular, the role of the 'open method of co-ordination' (OMC). The baptism of OMC at Lisbon has created a minor cottage industry within EU studies. The papers here represent a coming-of-age of those studies in their willingness to engage critically with OMC and to question commonly-held assumptions as to its nature.

Chiattelli's paper offers us an overview of the journey from the Lisbon Strategy of 2000 to the relaunch of Lisbon II in 2005. He is sceptical as to the extent to which the relaunch is capable of remedying the deficiencies in soft governance techniques identified in the Kok report which preceded and influenced the European Commission's mid-term review. Deganis, in her analysis of the European Employment Strategy (EES), and using Sabatier's 'advocacy coalition framework', indicates that the Commission has sought to establish a directing role for itself within the EES that echoes its 'right of initiative' role in the traditional Community Method. Her paper provides evidence that, in terms of working methods, the Commission's agenda-setting role has not been displaced by that of a European Council directing decentralised co-ordination. Bernhard, likewise, indicates that in the OMC process on social inclusion, there is perhaps more of a 'top-down' steer to the process than is implicated by rationalising $O M C$ as an open decentralised learning 
process. He suggests that there is also a parallel process of paradigm dissemination at play which tends to shape a narrower conceptualisation of social exclusion as exclusion from the labour market, compared to the sort of multi-dimensional definition of social exclusion found elsewhere in EU policy discourse. MacPhail's paper on the EES questions assumptions that OMC provides a more participative process at least as regards the participation of sub-national authorities. As her case study of Scotland identifies, older modes of governance like the Structural Funds may provide more opportunities and incentives for sub-national engagement in EU governance than co-ordination processes which appear remote and irrelevant to the policy processes at sub-national level.

Kalegeropoulou offers a more optimistic assessment of the possibilities for OMC processes to keep issues such as pensions reform high on the political agenda. Importantly, her paper avoids dichotomising old and new forms of governance by considering the potential interaction between $O M C$ and the proposed directive on the portability of supplementary pensions. Finally, in her contribution, Tanasescu illustrates that insofar as the Lisbon Strategy seeks to reconcile regulation with competitiveness through resort to alternative modes of environmental governance, empirical evidence casts doubt on their effectiveness (while also indicating certain preconditions for their more effective deployment). At the same time, the ambiguous relationship between the relaunched Lisbon Strategy and the Sustainable Development Strategy suggests a continuing tension between environmental and economic goals.

In their coverage and in the quality of their analysis, these papers demonstrate the vitality of postgraduate EU studies. The Journal hopes that this special issue will inspire other graduate researchers - from all disciplines - to contribute to the debate and to use the Journal as a vehicle for disseminating ideas and analysis on the EU.

Kenneth Armstrong Professor of European Union Law Convenor of the ESRC Seminar Series: 'Implementing the Lisbon Strategy: Policy Co-ordination Through "Open" Methods www.laws.qmul.ac.uk/Lisbon

The financial support of the ESRC under research award RES-451-26-0030 is acknowledged with gratitude. 